\title{
Microorganisms with Claimed Probiotic Properties: An Overview of Recent Literature
}

\section{Sabina Fijan}

Faculty of Health Sciences, University of Maribor, Žitna ulica 15, 2000 Maribor, Slovenia; E-Mail: sabina.fijan@um.si; Tel.: +386-2-300-47-52

Received: 30 January 2014; in revised form: 17 March 2014 / Accepted: 25 March 2014 / Published: 5 May 2014

\begin{abstract}
Probiotics are defined as live microorganisms, which when administered in adequate amounts, confer a health benefit on the host. Health benefits have mainly been demonstrated for specific probiotic strains of the following genera: Lactobacillus, Bifidobacterium, Saccharomyces, Enterococcus, Streptococcus, Pediococcus, Leuconostoc, Bacillus, Escherichia coli. The human microbiota is getting a lot of attention today and research has already demonstrated that alteration of this microbiota may have far-reaching consequences. One of the possible routes for correcting dysbiosis is by consuming probiotics. The credibility of specific health claims of probiotics and their safety must be established through science-based clinical studies. This overview summarizes the most commonly used probiotic microorganisms and their demonstrated health claims. As probiotic properties have been shown to be strain specific, accurate identification of particular strains is also very important. On the other hand, it is also demonstrated that the use of various probiotics for immunocompromised patients or patients with a leaky gut has also yielded infections, sepsis, fungemia, bacteraemia. Although the vast majority of probiotics that are used today are generally regarded as safe and beneficial for healthy individuals, caution in selecting and monitoring of probiotics for patients is needed and complete consideration of risk-benefit ratio before prescribing is recommended.
\end{abstract}

Keywords: Lactic-acid bacteria; Lactobacillus; Bifidobacterium; Saccharomyces; Enterococcus; Streptococcus; Pediococcus; Leuconostoc; Bacillus; Escherichia coli 


\section{Background}

It is scientifically established that certain species of microorganisms make us sick and can even kill us. Among the deadliest microorganisms throughout history, either due to global number of deaths, mortality rate or production of lethal toxins, we usually include Yersinia pestis, influenza virus, AIDS/HIV virus, Clostridium tetani, Mycobacterium tuberculosis and Vibrio cholerae, just to name a few. Recently; many multi-drug resistant bacteria have been causing important health-care associated infections and dangerous serotypes have been causing serious emerging food-poisonings due to production of enterotoxins. Some of these medically important bacteria include: methicillin-resistant Staphylococcus aureus (MRSA), vancomycin-resistant enterococci (VRE), extended-spectrum beta-lactamase (ESBL) producing Enterobacteriaceae, multi-drug resistant Pseudomonas aeruginosa, multi-drug resistant Mycobacterium tuberculosis and Enterohemorrhagic Escherichia coli (EHEC) $[1,2]$.

Therefore; throughout the history of microbiology, most human studies have been focused on the disease-causing organisms found on or in people; whilst fewer studies have examined the benefits of the resident bacteria [3]. As noted in several reviews [4,5] the endogenous flora of the human body is poorly understood. However, we are surrounded by an important biological system of microorganisms that live in or on the human body and are beneficial. This biological system is the human microbiome. It has been known for some time that the human body is inhabited by at least 10 times more bacteria than the number of human cells in the body, and that the majority of those bacteria are found in the human gastrointestinal tract $[3,6]$. The composition of the gut microbiota varies during childhood until the individual reaches adulthood [7]. The relationship between the host and the gut microbiota is symbiotic. The mainly commensal intestinal microbiota contribute to the enhancing resistance against infections, differentiation of the host immune system, synthesis of certain nutrients such as vitamins, short-chain fatty acids and other low molecular mass molecules. However, little is really systematically known about the body of evidence to evaluate the role of the gut indigenous microflora and the consequences of microecological imbalances as well as the metabolic consequences that may impact progression of metabolic disease [8,9].

After the successful human genome project that mapped the entire human genome, the International Consortium on the Microbiome has launched similar projects of mapping the human microbiome with two major arms: the NIH Human microbiome project and the EU FP 7 MetaHit Project [3]. An important observation is that, while our health is certainly influenced by genes, it may also be even more powerfully influenced by our microbiome [10]. Although human microbiota studies have already been conducted, projects that investigate patient perceptions of bioengineered probiotics and analysing existing regulatory frameworks for the federal regulation of probiotics are of interest to public health and are therefore funded.

\section{Probiotics as Microorganisms with Health Benefits}

According to the Food and Agriculture Organisation of the United Nations (FAO) and the World Health Organisation (WHO) [11,12] probiotics are defined as live microorganisms, which when administered in adequate amounts, confer a health benefit on the host. This definition of probiotics is 
also adopted by the International Scientific Association for Probiotics and Prebiotics (ISAPP) and is used in most scientific publications. However, this definition is not accepted by European Food Safety Authority (EFSA) or the U.S. Food and Drug Administration (FDA) $[13,14]$ at the moment since they insist that the health claim incorporated in the definition is not measurable due to the fact that commercial markets have outpaced the ability of science to substantiate the evidence. As a consequence, no substantiated health claims have been approved for any probiotic in the U.S. [15]. However, health claims, such as treatment and cures of disease using probiotics, are measurable and can be proven with similar type of studies as are conducted for drugs (double-blinded, randomized, placebo-controlled human trials). Although the benefits of consuming fermented foods have been known to humankind for centuries; long before microorganisms were discovered; the concept of administering microorganisms in order to confer a positive health benefit started over a century ago when Metchnikoff theorized that health could be enhanced, and also senility could be delayed, by manipulating the intestinal microbiome with host-friendly bacteria found in yogurt [16].

Over the last two decades there has been growing interest on both basic and clinical science in probiotics which has resulted in over 6000 publications in the biomedical literature, with over $60 \%$ published in the last 5 years, some in the top ranking scientific journals [14]. The most common types of microorganisms used as probiotics are lactic acid bacteria and bifidobacteria, although other bacteria and certain yeasts are also used [17]. It is important to stress that the biological effects of probiotics are strain specific and that the success or failure of one strain cannot be extrapolated to another strain. Thus proper strain identification using novel molecular and based technologies is imperative [18]. Species identification can be performed by 16S rRNA gene sequence analysis and DNA-DNA hybridisation techniques. Strain identification can further be performed by various reproducible molecular methods or using unique phenotypic traits. Examples of molecular methods are: pulsed field gel electrophoresis and randomly amplified polymorphic DNA. Phenotype traits for strain identification include: determining the presence of extrachromosomal genetic elements, fermentation of a range of sugars and detection of final fermentation products obtained from glucose utilization [12].

Another important aspect to mention when claiming the health benefits of probiotics is that a beneficial effect can only be demonstrated by in vivo studies [12]. Although in vitro studies or animal models cannot prove a probiotic effect, they can be used to characterise a possible mechanism of probiotic action, determine the safety of probiotic microorganisms or convey other knowledge of probiotic strains. Thus, in vitro studies provide the first step in evaluating probiotics for food use and should be followed by double-blinded, randomized, placebo-controlled human trials. Appropriate target-specific in vitro studies that correlate with in vivo are recommended. For example in vitro bile salts resistance was shown to correlate with gastric survival in vivo [19]. Knowledge on probiotic strains is therefore the first step conducted through in vitro studies. The most important properties of strains to even be considered for probiotic use include: resistance to gastric acidity, bile acid resistance, adherence to mucus and/or human epithelial cells and cell lines, antimicrobial activity against potentially pathogenic bacteria or fungi, ability to reduce pathogen adhesion to surfaces, bile salt hydrolase activity, enhancing viability of probiotics. [12,20-24].

The aim of this overview of recent literature was to present the most common microorganisms with their recently claimed probiotic properties. 


\section{Methods}

A literature overview of the PubMed database using the keywords: 'probiotic' and 'microorganisms' yielded 920 publications. Of these; 682 were published in the last 10 years (74\%); and 492 were published in the last 5 years (53\%). Thomson Reuters Web of science yielded 1078 publications using the keywords: 'probiotic' and 'microorganisms' since 1970, of these 886 (82.1\%) were published in the last 10 years and $676(62.7 \%)$ were published in the last five years. The literature overview for this article included other databases such as ScienceDirect and Google search as well as other keyword combinations (individual microorganism/probiotic). Unless otherwise relevant, only a selection of the most recent articles focused on probiotic microorganisms and their health claims were chosen to be included in this overview. Of course, this does not mean that all important research on probiotic microorganisms was included.

\section{Results and Discussion}

\subsection{Specific Strains with Probiotic Properties in the Genus Lactobacillus}

The genus Lactobacillus includes various Gram positive facultative anaerobic or microaerophilic rod-shaped bacteria. They are a major part of the lactic acid bacteria (LAB) group (including Lactobacillus, Lactococcus, Enterococcus, Oenococcus, Pediococcus, Streptococcus and Leuconostoc species) that can convert hexose sugars to lactic acid thus producing an acid environment which inhibits the growth of several species of harmful bacteria [25]. In humans, Lactobacilli are normally present in the vagina, gastrointestinal tract [26] and are together with Bifidobacterium one of the first bacteria to colonize the infant gut after delivery [27]. The complete genome sequences of the following commensal Lactobacilli have been published: Lactobacillus plantarum, L. johnsonii, L. acidophilus, L. sakei, L. bulgaricus, L. salivarius [25].

Some Lactobacilli are used for the production of yogurt, cheese, sauerkraut, pickles, sourdough, wine and other fermented products [28-30]. In all cases, sugars are metabolised into lactic acid; thus creating a hostile environment for spoilage microorganisms and enabling food preservation.

It has been found that infants with food allergies exhibit an imbalance between beneficial and potentially harmful bacteria, i.e., decreased Lactobacillus, Bifidobacteria and Enterococcus species and increased coliforms, Staphylococcus aureus and Clostridium species; suggesting that microbial inhabitants of the human body, may play either a pathogenic or protective role in allergies. Based on this data, many clinical trials addressing the use of probiotics in the context of allergic disorders have been conducted in children. However, currently, no conclusive item may be drawn [31].

Lactobacilli have received tremendous attention due to their health-promoting properties [26]. However, a very important fact that is sometimes overlooked by scientists is that most Lactobacilli do not form stable and numerically significant populations in the human intestinal tract, especially in the small intestine where they are presumed to form epithelial associations [26]. Similarly, in the research on modulating intestinal bifidobacteria and Lactobacilli after one week supplementation with commercial probiotic food supplements, only a significant increase in the intestinal Lactobacillus acidophilus group was observed and even this increase disappeared after a few days [32]. The authors concluded that short-term daily intake of live probiotic cells is insufficient in modulating the intestinal 
bifidobacteria and Lactobacilli. Lactobacilli such as: Lactobacillus acidophilus, L. casei, L. paracasei, L. rhamnosus, L. delbrueckii subsp. bulgaricus, L. brevis, L. johnsonii, L. plantarum and L. fermentum are commonly used as probiotic products. Although Lactobacilli are often described as indigenous inhabitants of the human intestinal tract, they are more likely to be autochthonous of the oral cavity or fermented foods [26,32].

Studies have shown that certain strains of Lactobacilli are effective in preventing antibiotic-associated diarrhoea [33,34]. Lactobacilli species are commonly selected as probiotics since they express many crucial properties such as: high tolerance to acid and bile, capability to adhere to intestinal surfaces, withstanding low $\mathrm{pH}$, gastric juice, inhibiting potentially pathogenic species (antimicrobial activity), resisting antibiotics, producing exopolysaccharides and removing cholesterol $[20,35,36]$. Lactobacillus rhamnosus CRL1505 has even been effective in reducing viral-associated pulmonary damage through controlling immune-coagulative responses and clearing respiratory viruses [37]. In a published meta-analysis [38] it has been shown that even though the probiotic strains of Lactobacillus were safe and effective in preventing recurrent urinary tract infections in adult women, the authors concluded that more randomized clinical trials should be conducted to make a more definitive recommendation.

Sometimes probiotic 'cocktails' comprising of various strains are used [39-41]. Several probiotic strains of microorganisms are effective in competing against common causes of travellers' diarrhoea [39,42] caused mostly by bacterial pathogens such as: one of the seven types of diarrheagenic Escherichia coli, Campylobacter jejuni and Shigella species. The most commonly used probiotic microorganisms against these pathogens are: Lactobacillus acidophilus, Lactobacillus rhamnosus GG, Saccharomyces boulardii, Bifidobacterium bifidum and Bacillus coagulans. Using Lactobacilli and other probiotics together with antibiotics also seems to be promising for the treatment of bacterial vaginosis, although more well-designed randomized controlled trials with standard methodologies and larger patient size are needed to inconclusively prove benefits [39].

The review of randomized control trials on the use of probiotics for functional constipation [43] revealed that the favourable treatment for adults was with Bifidobacterium lactis DN-173 010, Lactobacillus casei Shirota and Escherichia coli Nissle 1917. A beneficial effect on children was shown with Lactobacillus casei rhamnosus Lcr35. In the review of probiotic safety during pregnancy [41] it was found that Lactobacillus and Bifidobacterium had no effect on the incidence of Caesarean section, birth weight or gestational age and no malformations were reported. The study [44] monitoring one month administration of a multi-strain probiotic capsule containing: Lactobacillus acidophilus, Lactobacillus delbrueckii subsp. bulgaricus, Bifidobacterium animalis subsp. lactis and Streptococcus thermophilus gave indecisive results, as no difference in the colonic microflora of patients with colitis (Crohn's colitis or ulcerative colitis) was observed.

On the other hand, a liver abscess caused by a Lactobacillus rhamnosus that was not distinguishable from the probiotic strain L. rhamnosus GG [45] and Lactobacillus endocarditis caused by $L$. rhamnosus (strain not specified) have been reported [46]. Although both reports [45,46] gave no information on the origin of infection; both reports highlight the importance of strain identification. It is also important to add that both articles were dated from the year 1999 when methods for exact strain identification were not as perfected as today. 


\subsection{Specific Strains with Probiotic Properties in the Genus Bifidobacterium}

The genus Bifidobacterium includes various Gram positive non-motile anaerobic bacteria. They are endosymbiotic inhabitants of the gastrointestinal tract and vagina of mammals, including humans [47]. Strains of the genus Bifidobacterium are also often used as probiotic bacteria as they are known for their variety of resistance mechanisms to bile salts, which is important since the beneficial effects of probiotic bacteria must be generated in the presence of this biological fluid.

It has even been proven that although bile tolerance is strain dependent, both wild type-bile sensitive bifidobacteria and Lactobacilli strains can progressively adapt to the presence of bile salts by subculturing and gradually increasing concentration of bile [36,48]. Several strains of bifidobacteria are considered as important probiotics including: Bifidobacterium infantis, B. adolescentis, B. animalis subsp animalis, B. animalis subsp lactis, B. bifidum, B. longum, B. breve. Companies often use trademark names for some of these bifidobacteria by inventing scientific sounding commercial names.

As mentioned before Bifidobacterium species together with other probiotics have been proven to treat constipation [43], travellers' diarrhoea [39], antibiotic-associated diarrhoea [34], maintaining remission of disease activity of gut inflammation and moderate ulcerative colitis [49,50], prevention as well as treatment of necrotizing enterocolitis in newborns [51], reduction of radiation induced diarrhoea [52], reducing the development of disease risk for eczema, food allergies [53], cholesterol-lowering capacities [36].

\subsection{Specific Strains with Probiotic Properties in the Genus Saccharomyces}

The genus Saccharomyces includes various yeasts such as: Saccharomyces cerevisiae (used for making wine, bread, beer), Saccharomyces bayanus (used for making wine) and Saccharomyces boulardii used in medicine as a probiotic. Saccharomyces yeasts also form symbiotic matrices with bacteria to form kefir [54] and are sometimes a component of kombucha [55].

$S$. boulardii is often marketed as a probiotic in a lyophilized form to treat diarrhoea while maintaining an excellent reputation for safety [39]. Most reports show a clinical benefit of $S$. boulardii in decreasing the duration of diarrhoea regardless of the cause and thus reducing hospital stay resulting in social and economic benefits [7,33,56-58]. Administration of $S$. boulardii has shown positive effects for patients with irritable bowel syndrome [59], preventing and treating relapses of inflammatory bowel disease and for treating moderate symptoms of ulcerative colitis [60,61]. Recurrent pseudomembranous colitis infection caused by Clostridium difficile can also be significantly reduced by administration of daily dosages of $S$. boulardii together with standard antibiotics [62]. In the previously mentioned review of probiotic safety during pregnancy [41] no malformations were reported. On the other hand, it must not be neglected that in immunocompromised individuals or other patients, S. boulardii can cause fungemia or localised infections $[63,64]$.

\subsection{Specific Strains with Probiotic Properties in the Genus Lactococcus}

Lactococcus is a genus of Gram positive lactic acid bacteria that are commonly used in the dairy industry for manufacturing fermented products. They are important in preventing growth of spoilage bacteria in milk products due to acidification. They are also sometimes recommended as probiotics. 
Certain strains of Lactococcus lactis subsp. lactis have probiotic properties such as adhesion to vaginal epithelial cells and nisin production (Lactococcus lactis subsp. lactis CV56) $[65,66]$ and are also used to treat antibiotic-associated diarrhoea in combination with other probiotics [33].

\subsection{Specific Strains with Probiotic Properties in the Genera Streptococcus and Enterococcus}

The genera Streptococcus and Enterococcus are also part of the lactic acid bacteria and contain several strains associated with severe health-care associated infections such as: Streptococcus pyogenes, Streptococcus pneumoniae, vancomycin-resistant Enterococcus faecium [67]. However, other strains form part of the commensal human microbiome of the mouth, skin, and intestine, such as Enterococcus faecium PC4.1 [68] and others. Some strains have probiotic properties: such as Enterococcus durans [69] and Streptococcus thermophilus [70] (also used for the production of yogurt alongside Lactobacillus delbrueckii subsp. bulgaricus).

Although Enterococcus faecium has a long history of probiotic use, especially in preventing antibiotic-associated diarrhoea [34], certain strains are opportunistic pathogens that present a potential reservoir of antibiotic resistance and virulence genes (animal study) [71] and are therefore generally not treated as safe (GRAS) for humans, but represent important probiotics for animals [72,73].

\subsection{Specific Strains with Probiotic Properties in the Genus Bacillus}

The genus Bacillus includes Gram positive spore-forming aerobic or facultative aerobic members with claimed probiotic properties including: B. subtilis, B. coagulans, B. subtilis, B. cereus.

Bacillus coagulans together with other microorganisms has proven to be most successful in preventing or treating antibiotic-associated diarrhoea [34,42].

Bacillus subtilis spores have been considered as probiotics for animal consumption [74,75] and have been proposed for treating diarrhoea and H. pylori eradication in humans [76]. However, a report of a recurrent septicaemia in an immunocompromised patient due to treatment with spores of the probiotic strain B. subtilis [77] and four cases of nosocomial bacteraemia caused by absorption of an oral preparation containing B. subtilis spores [78] have shown the high risk of using Bacillus subtilis spores as probiotics to immunocompromised patients, and that ingestion is safe only for humans under normal host conditions [79].

B. cereus NVH 75/95 has also proven to be an efficient probiotic for animals [80]. Certain B. cereus strains are human-lethal and highly toxic, whereas other strains have probiotic properties [81].

Another report [82] highlighted the importance of confirming strain identities thus avoiding casual links between probiotic microorganisms and strains isolated from immune-suppressed hosts. This report also proved that the cholangitis due to Bacillus in a French hospital was not caused by a probiotic.

\subsection{Specific Strains with Probiotic Properties in the Genus Escherichia}

Although the genus Escherichia, which belongs to the Gram negative family Enterobacteriaceae, is mainly known for its severely virulent serotypes (e.g., E. coli O157:H7), Escherichia coli is a very common inhabitant of the lower intestine and even a probiotic strain is known: Escherichia coli Nissle 
1917 (EcN). As mentioned before Escherichia coli Nissle 1917 together with other probiotics have been proven to treat constipation [43] and inflammatory bowel disease [83]. This strain could also relieve gastrointestinal disorder, ulcerative colitis, Crohn's disease [84], even colon cancer [83], however more research is necessary.

\subsection{Claimed Health Benefits of Individual Probiotic Microorganisms}

Many publications using well-designed and well-conducted trials substantiate the health benefits of specific strains of probiotics on the risk reduction and management of a variety of diseases and conditions. Some of the documented health claims of probiotics proposed by their authors include: stimulation of various components of the immune system, gut immune response and intestinal homeostasis [85]; prevention and treatment of diarrhoea [33,39,42,86]; improvement of faecal properties and microbiota, treatment of irritable bowel syndrome, inflammatory bowel disease and constipation [43,59-61,85,86]; prevention and treatment of Clostridium difficile-associated diarrhoea in adults and children [62,87]; alleviation of symptoms of lactose intolerance and other food allergies [86]; prevention of necrotising enterocolitis in preterm infants [88-90]; decrease in plasma cholesterol level [35,85,91]; improvement of Helicobacter pylori eradication regimens [92]; therapeutic effects by supporting the immune response of HIV-infected children and adults [93,94], anti-proliferative activity on tumour cells [95,96]; reduction of viral-associated pulmonary damage through controlling immune-coagulative responses and clearing respiratory viruses [37]; immune-stimulatory properties of low molecular mass molecules produced by probiotic bacteria [97]. Although probiotics have even been proposed as treatment for eczema [98], randomized controlled trials to date do not have sufficient evidence to recommend probiotics as primary prevention $[99,100]$. It is important to add that much more must be done to identify scientifically proven mechanisms of action with translational pre-clinical safety studies as well as rigorous clinical trials. To prove a health claim sample sizes of trials must be sufficient, heterogeneity of study designs (targeted population) must be enabled and accurate identification of strains should be conducted.

Also, several animal studies have observed positive effects of probiotic administration [101-104] which can have a consequential positive effect on public health of humans by lowering antibiotic consumption for animals used in food production. This will consequently lower the presence of drugs and multi-resistant organisms in the environment (including drinking water). Studies on animals are also the basis for in vivo human trials resulting in complex knowledge. However, caution should be applied, as successful use of probiotics in animal studies does not necessarily mean that similar protocols will be successful for human trials, especially for patients. Such, was the case in the study on the use of probiotics in patients suffering severe acute pancreatitis where a significantly higher mortality was observed for the probiotics group than for the placebo group [105], although these results were unexpected in the light of the results of animal studies [106]. However, this case is not representative as normally a probiotic would not be administered to this category of patients with multi-organ failure. It was later postulated that an error in the treatment, which led to the adverse cascade of events that caused organ failure and ultimately death, was perhaps due to the high incidence of gut ischemia in the treatment group [107]. 
The most common probiotic microorganisms with claimed health benefits for humans from the most recent scientific literature are noted in Table 1. Where data was available, strain specific data was added in brackets before the reference.

Table 1. Recently published claimed health benefits of probiotic microorganisms.

\begin{tabular}{|c|c|c|}
\hline Genus & Species & Recently published health claims with references (strain specific date is noted where available) \\
\hline \multirow{9}{*}{ 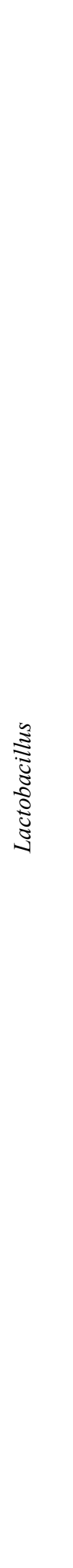 } & L. rhamnosus & $\begin{array}{l}\text { Reduction of viral-associated pulmonary damage (L. rhamnosus CRL1505) [37]; prevention and reduction } \\
\text { of severity of atopic dermatitis in children (L. rhamnosus GG) [108]; reduction of risk for developing } \\
\text { allergic disease (L. rhamnosus GG) [109], (L. rhamnosus HN001 [110]; anti-diabetic potential (various } \\
\text { strains from human infant faecal samples) [111]; prevention of necrotizing enterocolitis in newborns } \\
\text { (L. rhamnosus GG) [112]; prevention or treatment of bacterial vaginosis (L. rhamnosus GR-1) [113]; aid in } \\
\text { weight loss of obese women (L. rhamnosus CGMCC1.3724) [114]; treatment of acute gastroenteritis in } \\
\text { children (L. rhamnosus GG) [115]; reduction of risk for rhinovirus infections in preterm infants } \\
\text { (L. rhamnosus GG and L. rhamnosus ATCC 53103) [116]; protection of human colonic muscle from } \\
\text { lipopolysaccharide-induced damage (L.rhamnosus GG) [117] }\end{array}$ \\
\hline & L. acidophilus & $\begin{array}{l}\text { Treatment of travellers' diarrhoea [39]; reduction of hospital stay of children with acute diarrhoea [118]; } \\
\text { antifungal activity (L. acidophilus ATCC-4495) [119]; prevention or treatment of bacterial vaginosis [113]; } \\
\text { treatment of C. difficile-associated diarrhoea [119]; reduction of incidence of febrile urinary tract infections } \\
\text { in children [120]; reduction of irritable bowel syndrome symptoms [121]. }\end{array}$ \\
\hline & L. plantarum & $\begin{array}{l}\text { Prevention of endotoxin production [35]; antifungal activity (L. plantarum NRRL B-4496) [119] reduction } \\
\text { of irritable bowel syndrome symptoms [121]. }\end{array}$ \\
\hline & L. casei & $\begin{array}{l}\text { Treatment of functional constipation in adults (L. casei Lcr35 and L. casei Shirota) [43]; treatment of } \\
\text { C. difficile-associated diarrhoea [122]; restoration of vaginal flora of patient with bacterial vaginosis } \\
\text { (L. casei Lcr35) [123]; reduction of irritable bowel syndrome symptoms [121]; reduction of diarrhoea } \\
\text { duration of antibiotic-associated diarrhoea in geriatric patients (L. casei Shirota) [124]; immunomodulatory } \\
\text { mechanisms (L. casei Shirota) [125]; improvement of rheumatoid arthritis status (L. casei 01) [126]; } \\
\text { protection against Salmonella infection ( } L \text {. casei CRL-431) [127]; prevention of Salmonella-induced } \\
\text { synovitis [128]; treatment of intravaginal staphylococcosis (L. casei IMV B-7280) [129]. }\end{array}$ \\
\hline & $\begin{array}{l}\text { L. delbrueckii } \\
\text { subsp. } \\
\text { bulgaricus }\end{array}$ & $\begin{array}{l}\text { Antibiotic resistance of yogurt starter culture [130]; enhancement of systemic immunity in elderly } \\
\text { (L. delbrueckii subsp. bulgaricus } 8481 \text { ) [131]; antibacterial action against E. coli [132]; modulation of brain } \\
\text { activity [133]. }\end{array}$ \\
\hline & L. brevis & $\begin{array}{l}\text { Protective role in bile salt tolerance (L. brevis KB290) [134]; reduction in plague acidogenicity (L. brevis } \\
\text { CD2) [135]. }\end{array}$ \\
\hline & L. johnsonii & $\begin{array}{l}\text { Impact on adaptive immunity for protection against respiratory insults [136]; reduction of occurrence of } \\
\text { gastritis and risk of H. pylori infection (L. johnsonii MH-68) [137]; inhibition of S. sonnei activity } \\
\text { (L. johnsonii F0421) [138]; treatment of perennial allergic rhinitis in children together with levocetirizine } \\
\text { (L. johnsonii EM1) [139]. }\end{array}$ \\
\hline & L. fermentum & $\begin{array}{l}\text { Prevention or treatment of bacterial vaginosis (L. fermentum RC-14) [113]; blockage of adherence of } \\
\text { pathogenic microorganisms on vaginal epithelium [140]; antistaphylococcal action (L. fermentum ATCC } \\
\text { 11739) [141]; potential for reduction of insulin resistance and hypercholesterolemia (L. fermentum NCIMB } \\
5221) \text { [142]. }\end{array}$ \\
\hline & L. reuteri & $\begin{array}{l}\text { Reduction of low-density lipoprotein cholesterol (L. reuteri NCIMB 30242) [71]; treatment of acute } \\
\text { gastroenteritis in children [115]; reduction of diarrhoea duration in children (L. reuteri ATCC 55730) [143]; } \\
\text { management of infant colic (L. reuteri ATCC } 55730 \text { and L. reuteri DSM 17938) [144]; reduction of onset of } \\
\text { gastrointestinal disorders in infants (L. reuteri DSM 17938) [145]; reduction of frequency of proven sepsis, } \\
\text { feeding intolerance and duration of hospital stay in preterm infants (L. reuteri DSM 17938) [146]. }\end{array}$ \\
\hline
\end{tabular}


Table 1. Cont.

\begin{tabular}{|c|c|c|}
\hline Genus & Species & Recently published health claims with references (strain specific date is noted where available) \\
\hline \multirow{5}{*}{ 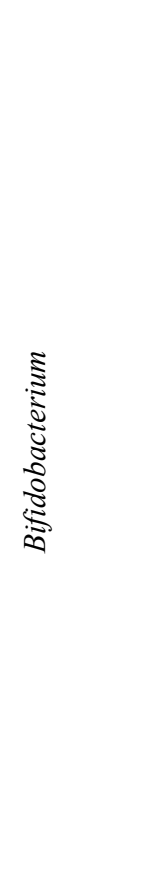 } & B. infantis & $\begin{array}{l}\text { Reduction of irritable bowel syndrome symptoms [122]; reduction of necrotizing enterocolitis in preterm } \\
\text { infants [147-149]. }\end{array}$ \\
\hline & $\begin{array}{l}\text { B. animalis } \\
\text { subsp. lactis }\end{array}$ & $\begin{array}{l}\text { Treatment of functional constipation in adults (B. animalis subsp. lactis DN-173 010) [43]; reduction of } \\
\text { incidence of febrile urinary tract infections in children [121]; modulation of brain activity [133]; } \\
\text { reduction of necrotizing enterocolitis in preterm infants [147]; reduction of total microbial counts in } \\
\text { dental plaque (B. animalis subsp. lactis DN-173 010) [150]; reduction of total cholesterol (B. animalis } \\
\text { subsp. lactis MB 202/DSMZ 23733) [151]; reduction of risk of upper respiratory illness (B. animalis } \\
\text { subsp. lactis BI-04) [152]. }\end{array}$ \\
\hline & B. bifidum & $\begin{array}{l}\text { Reduction of hospital stay of children with acute diarrhoea [118]; reduction of necrotizing enterocolitis in } \\
\text { preterm infants }[148,149] \text {; reduction of total cholesterol (B. bifidum MB 109/DSMZ 23731) [151]. }\end{array}$ \\
\hline & B. longum & $\begin{array}{l}\text { Prevention and treatment of necrotizing enterocolitis in newborns [51]; reduction of radiation induced } \\
\text { diarrhoea [52]; reduction of necrotizing enterocolitis with Bifidobacteria cocktail (B. breve, B. infantis, } \\
\text { B. bifidum, B. longum) [149]; reduction of irritable bowel syndrome symptoms [122]; treatment of } \\
\text { gastrointestinal diseases (B. longum CMCC P0001) [153]; perinatal intervention against onset of allergic } \\
\text { sensitization (B. longum CCM 7952) [154]. }\end{array}$ \\
\hline & B. breve & $\begin{array}{l}\text { Prevention and treatment of necrotizing enterocolitis in newborns [51]; reduction of necrotizing } \\
\text { enterocolitis with Bifidobacteria cocktail (B. breve, B. infantis, B. bifidum, B. longum) [149]; reduction of } \\
\text { cholesterol (B. breve MB 113/DSMZ 23732) [151]. }\end{array}$ \\
\hline 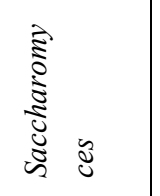 & S. boulardi & $\begin{array}{l}\text { Treatment of travellers' diarrhoea [39]; treatment and reduction of diarrhoea duration regardless of cause } \\
{[7,33,56-58] \text {; treatment of irritable bowel syndrome [59]; treatment of moderate ulcerative colitis }} \\
{[60,61] \text {; treatment and reduction of recurrent pseudomembrane colitis infection caused by C. difficile }} \\
\text { [62]; treatment of acute gastroenteritis in children [115]. }\end{array}$ \\
\hline 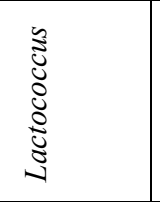 & $\begin{array}{l}\text { L. lactis subsp. } \\
\text { lactis }\end{array}$ & $\begin{array}{l}\text { Treatment of antibiotic-associated diarrhoea [33]; adhesion to vaginal epithelial cells (L. lactis subsp. } \\
\text { lactis KLDS4.0325) [65]; nisin production (L. lactis subsp. lactis CV56) [66]; modulation of brain } \\
\text { activity [133]; antimicrobial activity against C. difficile [155]; antimicrobial and probiotic properties } \\
\text { (L. lactis subsp. lactis ATCC 11454) [156]. }\end{array}$ \\
\hline \multirow{2}{*}{ 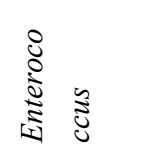 } & E. durans & $\begin{array}{l}\text { Antibiotic and antioxidant activity (E. durans LAB18s) [70], adherence to colonic tissue and } \\
\text { anti-inflammatory activity [157]. }\end{array}$ \\
\hline & E. faecium & Treatment of antibiotic-associated diarrhoea [34]; efficient animal probiotic [73]. \\
\hline 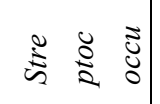 & S. thermophilus & $\begin{array}{l}\text { Reduction of irritable bowel syndrome symptoms [122]; antibiotic resistance of yogurt starter culture } \\
{[130] \text {; reduction of necrotizing enterocolitis in preterm infants }[147,148] \text {. }}\end{array}$ \\
\hline 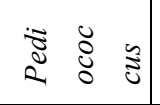 & P. acidilactici & $\begin{array}{l}\text { Pediocin production with antimicrobial and probiotic properties }(P . \text { acidilactici UL5) [156]; bacteriocin } \\
\text { production [158]; elimination of } H . \text { pylori infections (P. acidilactici BA28) [159]. }\end{array}$ \\
\hline 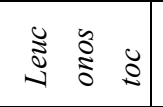 & $\begin{array}{l}\text { L. } \\
\text { mesenteroides }\end{array}$ & $\begin{array}{l}\text { Leucoin production, probiotic profile (survival at low } \mathrm{pH} \text {, in presence of bile salts, in presence of pepsin) } \\
\text { (L. mesenteroides } \mathrm{B} 7 \text { ) [160]. }\end{array}$ \\
\hline \multirow{3}{*}{ 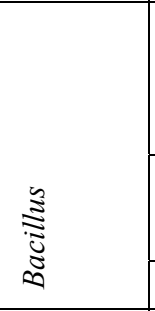 } & B. coagulans & $\begin{array}{l}\text { Treatment of antibiotic-associated diarrhoea [34,42], treatment of bacterial vaginosis (B. coagulans } \\
\text { ATCC PTA-11748) [161]; immunological support (B. coagulans GandenBC30) [162]; prevention of } \\
\text { caries in children [163]. }\end{array}$ \\
\hline & B. subtilis & $\begin{array}{l}\text { Efficient animal probiotic [74,75]; treatment of diarrhoea and aiding in } H . \text { pylori eradication }(B . \text { subtilis } \\
\text { R0179) [76]; production of nitric oxide [164]. }\end{array}$ \\
\hline & B. cereus & Efficient animal probiotic (B. cereus NVH75/95) [80]. \\
\hline 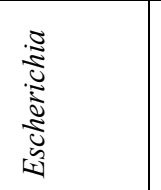 & $\begin{array}{l}\text { E. coli Nissle } \\
1917\end{array}$ & $\begin{array}{l}\text { Treatment of functional constipation in adults [43]; treatment of inflammatory bowel disease [83]; } \\
\text { treatment of gastrointestinal disorders [84]; pro-inflammatory potential [165]; prevention of surface } \\
\text { ocular diseases [166]; reduction of Salmonella enterica Typhimurium intestinal colonization by iron } \\
\text { competition [167]. }\end{array}$ \\
\hline
\end{tabular}


Some of the health claims of individual probiotic microorganisms noted in Table 1 are based on in vitro using cell cultures or animal models and others are based on in vivo studies. From the table we can see that health claims are very diverse and range from managing various gastrointestinal diseases or disorders to exhibiting antibiotic properties and reducing total cholesterol. Some authors even claim that probiotics reduce tumour growth, modulate brain activities and reduce allergies. However, many authors stress in their conclusions that more randomized double-blinded trials need to be conducted in the future before making recommendations.

\section{Conclusions}

This article shows that the research and subsequent knowledge on microorganisms with probiotic properties is by far not complete and we are probably only reaching the tip of the iceberg as there are many different strains of microorganisms with diverse health benefits.

The literature overview shows that, although the vast majority of probiotics are generally regarded as safe (GRAS) and beneficial for healthy individuals, caution is needed in selecting and monitoring of probiotics when administering probiotics to patients with compromised immune systems, leaky gut or critical illnesses. The most common observed adverse effects include: sepsis, fungemia and gastrointestinal ischemia. Therefore, while the overwhelming existing evidence suggests that probiotics are safe, complete consideration of risk-benefit ratio before prescribing is recommended [107].

Although it is a scientific fact that certain microorganisms can kill us, the questions arise: do certain microorganisms also keep us alive? Would it be more correct to imply that the post-modern rise of conditions and diseases such as obesity, celiac disease, asthma, allergy syndromes, type 1 diabetes and Chrohn's disease; are not only due to our genome but are also a result of the adaption of gastro-intestinal microorganisms caused by lifestyle changes, excessive intake of processed foods and sugar $[7,10,168]$ ? We cannot overlook the fact that microorganisms outnumber human cells by tenfold; the majority of which are found in the human intestinal tract [3]. Microorganisms play an important role in our gut associated lymphoid tissue, thus having profound influence on our immune system [169] and beyond. A dramatic manipulation of the intestinal microbiota involving faecal microbiota transplantation has shown remarkable clinical effectiveness for recurrent Clostridium difficile infection and ongoing studies are investigating effectiveness for other diseases [170], thus again proving the complexity of our intestinal microbiota.

Although the discovery of antibiotics was an important breakthrough in the 20th century and drugs such as penicillin and streptomycin have saved millions of lives, there is always collateral damage as our commensal microbiota is also affected [10,171]. Even though the intestinal microbiota is usually not permanently modulated with probiotic administration, this does not mean that during acute disruption of the sensitive intestinal microbiota balance, transiently present probiotics do not aid the permanent microbiota in restoring this balance.

With regard to probiotics it is also important to be careful with the science and not to oversell it $[168,172]$. Most probiotic products at the moment do not to go through pre-market approvals and are commonly used for a much wider range of scenarios in which their efficacy is not well established [173]. Therefore, future health claims concerning probiotics and their safety will critically depend on scientific evidence through science-based clinical studies on targeted population [174]. Another important issue is correct strain identification of each probiotic, for which expanding the 
internationally recognised culture collections of taxonomically classified and deposited probiotics is necessary [172]. This would assure strict use only of tested strains [175] with known profiles in compliance with regulatory pathways for 'fit for human use consumption' protocols.

Perhaps it will be possible that in the future probiotics will be used as approved drugs that will be prescribed together with/or instead of antibiotics for certain conditions such as ear infections or sinusitis [10]? An interesting concluding thought of this overview is that even though it is true that certain microorganisms can make us sick and even kill us, certain microorganisms are beneficial.

\section{Conflicts of Interest}

The author declares no conflict of interest.

\section{References}

1. Gruber, I.; Heudorf, U.; Werner, G.; Pfeifer, Y.; Imirzalioglu, C.; Ackermann, H.; Brandt, C.; Besier, S.; Wichelhaus, T.A. Multidrug-resistant bacteria in geriatric clinics, nursing homes, and ambulant care-prevalence and risk factors. Int. J. Med. Microbiol. 2013, 303, 405-409.

2. Fijan, S.; Šostar-Turk, S. Hospital textiles, are they a possible vehicle for healthcare-associated infections? Int. J. Environm. Res. Public Health 2012, 9, 3330-3343.

3. NIH HMP Working group; Peterson, J.; Garges, S.; Giovanni, M.; McInnes, P.; Wang, L.; Schloss, J.A.; Bonazzi, V.; McEwen, J.E.; Wetterstrand, K.A.; et al. The NIH Human Microbiome Project. Genome Res. 2009, 19, 2317-2323.

4. Relman, D.A. New technologies, human-microbe interactions, and the search for previously unrecognized pathogens. J. Infect. Dis. 2002,186, S254-S258.

5. Relman, D.A.; Falkow, S. The meaning and impact of the human genome sequence for microbiology. Trends. Microbiol. 2001, 9, 206-208.

6. Savage, D.C. Microbial ecology of the gastrointestinal tract. Annu. Rev. Microbiol. 1977, 31, 107-133.

7. Vieira, A.; Teixeira, M.M.; Martins, F.S. The role of probiotics and prebiotics in inducing gut immunity. Front. Immunol. 2012, 4, 445, doi:10.3389/fimmu.2013.00445.

8. Ubeda, C.; Pamer, E.G. Antibiotics, microbiota, and immune defense. Trends Immunol. 2012, 33, 459-466.

9. Ramakrishna, B.S. Role of the gut microbiota in human nutrition and metabolism. J. Gastroenterol. Hepatol. 2013, 4, 9-17.

10. Specter, M. Germs are us. Bacteria make us sick. Do they also keep us alive? New Yorker 2012, $22,32-39$.

11. Food and Agriculture Organization of the United Nations/World Health Organization FAO/WHO. Health and Nutritional Properties of Probiotics in Food including Powder Milk with Live Lactic Acid Bacteria. 2001. Available online: http://www.who.int/foodsafety/publications/ fs_management/en/probiotics.pdf (accessed on 20 January 2014).

12. Food and Agriculture Organization of the United Nations/World Health Organization FAO/WHO. Guidelines for the Evaluation of Probiotics in Food; Joint FAO/WHO Working Group on Drafting Guidelines for the Evaluation of Probiotics in Food: London, Ontario, Canada, 2002. 
13. Guidance on the Implementation of Regulation N81924/2006 on Nutrition and Health Claims Made on Foods. Conclusions of the Standing Committee on the Food Chain and Animal Health. Available online: http://ec.europa.eu/food/food/labellingnutrition/claims/guidance_claim_14-1207.pdf (accessed on 20 January 2014).

14. Rijkers, G.T.; De Vos, W.M.; Brummer, R.J.; Morelli, L.; Corthier, G.; Marteau, P. Health benefits and health claims of probiotics: Bridging science and marketing. Br. J. Nutr. 2011, 106, 1291-1296.

15. Reid, G. Microbiology: Categorize probiotics to speed research. Nature 2012, 485, 446, doi:10.1038/485446a.

16. Mackowiak, P.A. Recycling metchnikoff: Probiotics, the intestinal microbiome and the quest for long life. Front. Public Health. 2013, 1, 52, doi:10.3389/fpubh.2013.00052.

17. Didari, T.; Solki, S.; Mozaffari, S.; Nikfar, S.; Abdollahi, M. A systematic review of the safety of probiotics. Expert Opin Drug Saf. 2014, 13, 227-239.

18. Aza1s-Braesco, V.; Bresson, J.L.; Guarner, F.; Corthier, G. Not all lactic acid bacteria are probiotics, ... but some are. Br. J. Nutr. 2010, 103, 1079-1081.

19. Conway, P.L.; Gorbach, S.L.; Goldin, B.R. Survival of lactic acid bacteria in the human stomach and adhesion to intestinal cells. J. Dairy Sci. 1987, 70, 1-12.

20. Tulumoglu, S.; Yuksekdag, Z.N.; Beyatli, Y.; Simsek, O.; Cinar, B.; Yaşar, E. Probiotic properties of Lactobacilli species isolated from children's feces. Anaerobe 2013, 24, 36-42.

21. Sarkar, S. Approaches for enhancing the viability of probiotics: A review. Br. Food J. 2010, 112, 329-349.

22. Seale, J.V.; Millar, M. Probiotics: A new frontier for infection control. J. Hosp. Inf. 2013, 84, 1-4.

23. Anwar, A.A.; Thikra, A.A.; Saeed, A.M. Adhesion, autoaggregation and hydrophobicity of six Lactobacillus strains. Br. Microbiol. Res. J. 2014, 4, 381-391.

24. Ganguly, N.K.; Bhattacharya, S.K.; Sesikeran, B.; Nair G.B.; Ramakrishna, B.S.; Sachdev, H.P.S.; Batish, V.K.; Kanagasabapathy, A.S.; Muthuswamy, V.; Kathuria, S.C.; et al. ICMR-DBT guidelines for evaluation of probiotics in food. Indian J. Med. Res. 2011, 134, 22-25.

25. Makarova, K.; Slesarev, A.; Wolf, Y.; Sorokin, A.; Mirkin, B.; Koonin, E.; Pavlov, A.; Pavlova, N.; Karamychev, V.; Polouchine, N.; et al. Comparative genomics of the lactic acid bacteria. Proc. Natl. Acad. Sci. USA 2006, 103, 15611-15616.

26. Walter, J. Ecological role of Lactobacilli in the gastrointestinal tract: Implications for fundamental and biomedical research. Appl. Environ. Microbiol. 2008, 74, 4985-4996.

27. Walker, W.A. Initial intestinal colonization in the human infant and immune homeostasis. Ann. Nutr. Metab. 2013, 63, 8-15.

28. Siragusa, S.; De Angelis, M.; Calasso, M.; Campanella, D.; Minervini, F.; Di Cagno, R.; Gobbetti, M. Fermentation and proteome profiles of Lactobacillus plantarum strains during growth under food-like conditions. J. Proteomics. 2013, 96, 366-380.

29. De Vuyst, L.; Van Kerrebroeck, S.; Harth, H.; Huys, G.; Daniel, H.M.; Weckx, S. Microbial ecology of sourdough fermentations: Diverse or uniform? Food Microbiol. 2014, 37, 11-29.

30. Bauer, R.; du Toit, M.; Kossmann, J. Influence of environmental parameters on production of the acrolein precursor 3-hydroxypropionaldehyde by Lactobacillus reuteri DSMZ 20016 and its accumulation by wine Lactobacilli. Int. J. Food Microbiol. 2010, 137, 28-31. 
31. Compare, D.; Nardone, G. The role of gut microbiota in the pathogenesis and management of allergic diseases. Eur. Rev. Med. Pharmacol. Sci. 2013, 17, 11-17.

32. Taverniti, V.; Scabiosi, C.; Arioli, S.; Mora, D.; Guglielmetti, S. Short-term daily intake of 6 billion live probiotic cells can be insufficient in healthy adults to modulate the intestinal bifidobacteria and Lactobacilli. J. Funct. Foods. 2013, 6, 482-491.

33. Johnston, B.C.; Goldenberg, J.Z.; Vandvik, P.O.; Sun, X.; Guyatt, G.H. Probiotics for the prevention of pediatric antibiotic-associated diarrhea. Cochrane Database Syst. Rev. 2011, 11, CD004827, doi: 10.1002/14651858.CD004827.pub2.

34. Hempel, S.; Newberry, S.J.; Maher, A.R.; Wang, Z.; Miles, J.N.; Shanman, R.; Johnsen, B.; Shekelle, P.G. Probiotics for the prevention and treatment of antibiotic- associated diarrhea: A systematic review and meta-analysis. JAMA 2012, 307, 1959-1969.

35. Lee, S.J.; Bose, S.; Seo, J.G.; Chung, W.S.; Lim, C.Y.; Kim, H. The effects of co-administration of probiotics with herbal medicine on obesity, metabolic endotoxemia and dysbiosis: A randomized double-blind controlled clinical trial. Clin. Nutr. 2013, doi:10.1016/j.clnu.2013.12.006.

36. Ruiz, L.; Margolles, A.; Sánchez, B. Bile resistance mechanisms in Lactobacillus and Bifidobacterium. Front Microbiol. 2013, 4, 396, doi:10.3389/fmicb.2013.00396.

37. Zelaya, H.; Tsukida, K.; Chiba, E.; Marranzino, G.; Alvarez, S.; Kitazawa, H.; Agüero, G.; Villena, J. Immunobiotic Lactobacilli reduce viral-associated pulmonary damage through the modulation of inflammation-coagulation interactions. Int. Immunopharmacol. 2014, 19, 161-173.

38. Grin, P.M.; Kowalewska, P.M.; Alhazzan, W.; Fox-Robichaud, A.E. Lactobacillus for preventing recurrent urinary tract infections in women: Meta-analysis. Can. J. Urol. 2013, 20, 6607-6614.

39. McFarland, L.V. Meta-analysis of probiotics for the prevention of traveler's diarrhea. Travel Med. Infect. Dis. 2007, 5, 97-105.

40. Senok, A.C.; Verstraelen, H.; Temmerman, M.; Botta, G.A. Probiotics for the treatment of bacterial vaginosis. Cochrane Database Syst Rev. 2009, 7, CD006289, doi:10.1002/14651858.CD006289.pub2.

41. Dugoua, J.J.; Machado, M.; Zhu, X.; Chen, X.; Koren, G.; Einarson, T.R. Probiotic safety in pregnancy: A systematic review and meta-analysis of randomized controlled trials of Lactobacillus, Bifidobacterium, and Saccharomyces spp. J. Obstet. Gynaecol. Can. 2009, 31, $542-552$.

42. Doron, S.I.; Hibberd, P.L.; Gorbach, S.L. Probiotics for prevention of antibiotic-associated diarrhea. J. Clin. Gastroenterol. 2008, 42, S58-S63.

43. Chmielewska, A.; Szajewska, H. Systematic review of randomised controlled trials: Probiotics for functional constipation. World J. Gastroenterol. 2010, 16, 69-75.

44. Ahmed, J.; Reddy, B.S.; Mølbak, L.; Leser, T.D.; MacFie J. Impact of probiotics on colonic microflora in patients with colitis: A prospective double blind randomised crossover study. Int. J. Surg. 2013, 11, 1131-1136.

45. Rautio, M.; Jousimies-Somer, H.; Kauma, H.; Pietarinen, I.; Saxelin, M.; Tynkkynen, S.; Koskela, M. Liver abscess due to a Lactobacillus rhamnosus strain indistinguishable from L. rhamnosus strain GG. Clin. Infect. Dis. 1999, 28, 1159-1160.

46. Mackay, A.D.; Taylor, M.B.; Kibbler, C.C.; Hamilton-Miller, J.M.T. Lactobacillus endocarditis caused by a probiotic organism. Clin. Microbiol. Infect. 1999, 5, 290-292. 
47. Chen, J.; Cai, W.; Feng, Y. Development of intestinal bifidobacteria and Lactobacilli in breast-fed neonates. Clin Nutr. 2007, 26, 559-566.

48. Noriega, L.; Cuevas, I.; Margolles, A.; de los Reyes-Gavilán, C.G. Deconjugation and bile salts hydrolase activity by Bifidobacterium strains with acquired resistance to bile. Int. Dairy J. 2006, $16,850-855$.

49. Dylag, K.; Hubalewska-Mazgaj, M.; Surmiak, M.; Szmyd, J.; Brzozowski, T. Probiotics in the mechanism of protection against gut inflammation and therapy of gastrointestinal disorders. Curr. Pharm. Des. 2014, 20, 1149-1155.

50. Aloisio, I.; Santini, C.; Biavati, B.; Dinelli, G.; Cencič, A.; Chingwaru, W.; Mogna, L.; Di Gioia, D. Characterization of Bifidobacterium spp. strains for the treatment of enteric disorders in newborns. Appl. Microbiol. Biotechnol. 2012, 96, 561-576.

51. Di Gioia, D.; Aloisio, I.; Mazzola, G.; Biavati, B. Bifidobacteria: their impact on gut microbiota composition and their applications as probiotics in infants. Appl. Microbiol. Biotechnol. 2014, 98, 563-577.

52. Demers, M.; Dagnault, A.; Desjardins, J.A. Randomized double-blind controlled trial: Impact of probiotics on diarrhea in patients treated with pelvic radiation. Clin. Nutr. 2013, doi:10.1016/j.clnu.2013.10.015.

53. Isolauri, E.; Rautava, S.; Salminen, S. Probiotics in the development and treatment of allergic disease. Gastroenterol. Clin. North. Am. 2012, 41, 747-762.

54. Witthuhn, R.C.; Schoeman, T., Britz, T.J. Characterisation of the microbial population at different stages of Kefir production and Kefir grain mass cultivation. Int. Dairy J. 2005, 15, 383-389.

55. Marsh, A.J.; O'Sullivan, O.; Hill, C.; Ross, R.P.; Cotter, P.D. Sequence-based analysis of the bacterial and fungal compositions of multiple kombucha (tea fungus) samples. Food Microbiol. 2014, 38, 171-178.

56. Dinleyici, E.C.; Eren, M.; Ozen, M.; Yargic, Z.A.; Vandenplas, Y. Effectiveness and safety of Saccharomyces boulardii for acute infectious diarrhea. Expert Opin. Biol. Ther. 2012, 12, 395-410.

57. Shan, L.S.; Hou, P.; Wang, Z.J.; Liu, F.R.; Chen, N.; Shu, L.H.; Zhang, H.; Han, X.H.; Han, X.X.; Cai, X.X.; et al. Prevention and treatment of diarrhoea with Saccharomyces boulardii in children with acute lower respiratory tract infections. Benef. Microbes. 2013, 1, 329-334.

58. Szajewska, H.; Mrukowicz, J. Meta-analysis: Non-pathogenic yeast Saccharomyces boulardii in the prevention of antibiotic-associated diarrhoea. Aliment Pharmacol. Ther. 2005, 22, 365-372.

59. Choi, C.H.; Jo, S.Y.; Park, H.J.; Chang, S.K.; Byeon, J.S.; Myung, S.J. A randomized, double-blind, placebo-controlled multicenter trial of Saccharomyces boulardii in irritable bowel syndrome: Effect on quality of life. J. Clin. Gastroenterol. 2011, 45, 679-683.

60. Guslandi, M.; Mezzi, G.; Sorghi, M.; Testoni, P.A. Saccharomyces boulardii in maintenance treatment of Crohn's disease. Dig. Dis. Sci. 2000, 45, 1462-1464.

61. Guslandi, M.; Giollo, P.; Testoni, P.A. A pilot trial of Saccharomyces boulardii in ulcerative colitis. Eur. J. Gastroenterol. Hepatol. 2003, 15, 697-698.

62. Fitzpatrick, L.R. Probiotics for the treatment of Clostridium difficile associated disease. World J. Gastrointest. Pathophysiol. 2013, 4, 47-52 
63. Thygesen, J.B.; Glerup, H.; Tarp B. Saccharomyces boulardii fungemia caused by treatment with a probioticum. BMJ Case. Rep. 2012, doi:10.1136/bcr.06.2011.4412.

64. Hennequin, C.; Kauffmann-Lacroix, C.; Jobert, A.; Viard, J.P.; Ricour, C.; Jacquemin, J.L.; Berche, P. Possible role of catheters in Saccharomyces boulardii fungemia. Eur. J. Clin. Microbiol. Infect. Dis. 2000, 19, 16-20.

65. Yang, X.; Wang, Y.; Huo, G. Complete Genome Sequence of Lactococcus lactis subsp. lactis KLDS4.0325. Genome Announc. 2013, 1, doi:10.1128/genomeA.00962-13.

66. Gao, Y.; Lu, Y.; Teng, K.L.; Chen, M.L.; Zheng, H.J.; Zhu, Y.Q.; Zhong, J. Complete genome sequence of Lactococcus lactis subsp. lactis CV56, a probiotic strain isolated from the vaginas of healthy women. J. Bacteriol. 2011, 193, 2886-2887.

67. Hossain, Z. Bacteria: Streptococcus. Encyclop. Food Safety 2014, 1, 535-545.

68. Hadji-Sfaxi, I.; El-Ghaish, S.; Ahmadova, A.; Batdorj, B.; Le Blay-Laliberté, G.; Barbier, G.; Haertlé, T.; Chobert, J.M. Antimicrobial activity and safety of use of Enterococcus faecium PC4.1 isolated from Mongol yogurt. Food Contr. 2011, 22, 2020-2027.

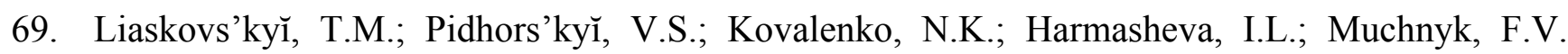
Identification of probiotic lactic acid bacteria strains. Mikrobiol Z. 2008, 70, 3-9.

70. Pieniz, S.; Andreazza, R.; Pereira, J.Q.; de Oliveira Camargo, F.A.; Brandelli, A. Production of selenium-enriched biomass by Enterococcus durans. Biol Trace. Elem. Res. 2013, 155, 447-454

71. Dirienzo. D.B. Effect of probiotics on biomarkers of cardiovascular disease: implications for heart-healthy diets. Nutr Rev. 2014, 72, 18-29.

72. Bednorz. C.; Guenther, S.; Oelgeschläger, K.; Kinnemann, B.; Pieper, R.; Hartmann, S.; Tedin, K.; Semmler, T.; Neumann, K.; Schierack, P.; Bethe, A.; Wieler, L.H. Feeding the probiotic Enterococcus faecium strain NCIMB 10415 to piglets specifically reduces the number of Escherichia coli pathotypes that adhere to the gut mucosa. Appl. Environ. Microbiol. 2013, 79, 7896-7904.

73. Cao, G.T.; Zeng, X.F.; Chen, A.G.; Zhou, L.; Zhang, L.; Xiao, Y.P.; Yang, C.M. Effects of a probiotic, Enterococcus faecium, on growth performance, intestinal morphology, immune response, and cecal microflora in broiler chickens challenged with Escherichia coli K88. Poult. Sci. 2013, 92, 2949-2955.

74. Larsen, N.; Thorsen, L.; Kpikpi, E.N.; Stuer-Lauridsen, B.; Cantor, M.D.; Nielsen, B.; Brockmann, E.; Derkx, P.M.; Jespersen, L. Characterization of Bacillus spp. strains for use as probiotic additives in pig feed. Appl. Microbiol. Biotechnol. 2013, doi:10.1007/s00253-013-5343-6.

75. Zokaeifar, H.; Babaei, N.; Saad, C.R.; Kamarudin, M.S.; Sijam, K.; Balcazar, J.L. Administration of Bacillus subtilis strains in the rearing water enhances the water quality, growth performance, immune response, and resistance against Vibrio harveyi infection in juvenile white shrimp, Litopenaeus vannamei. Fish Shellfish Immunol. 2014, 36, 68-74.

76. Tompkins, T.A.; Xu, X.; Ahmarani, J.A. comprehensive review of post-market clinical studies performed in adults with an Asian probiotic formulation. Benef. Microbes. 2010, 1, 93-106.

77. Oggioni, M.R.; Pozzi, G.; Balensin, P.E.; Galieni, P.; Bigazzi, C. Recurrent septicemia in an immunocompromised patient due to probiotic strains of Bacillus subtilis. J. Clin. Microbiol. 1998, $36,325-326$. 
78. Richard, V.; Auwera, P.; Snoeck, R.; Daneau, D.; Meunier, F. Nosocomial bacteremia caused by Bacillus species. Eur. J. Clin. Microbiol. Infect. Dis. 1988, 7, 783-785.

79. Hosoi, T.; Hirose, R.; Saegusa, S.; Ametani, A.; Kiuchi, K.; Kaminogawa, S. Cytokine responses of human intestinal epithelial-like Caco-2 cells to the nonpathogenic bacterium Bacillus subtilis (natto). Int. J. Food Microbiol. 2003, 82, 255-264.

80. Trapecar, M.; Leouffre, T.; Faure, M.; Jensen, H.E.; Granum, P.E.; Cencic, A.; Hardy, S.P. The use of a porcine intestinal cell model system for evaluating the food safety risk of Bacillus cereus probiotics and the implications for assessing enterotoxigenicity. APMIS 2011, 119, 877-884.

81. Kamar, R.; Gohar, M.; Jéhanno, I.; Réjasse, A.; Kallassy, M.; Lereclus, D.; Sanchis, V.; Ramarao, N.J. Pathogenic potential of Bacillus cereus strains as revealed by phenotypic analysis. Clin. Microbiol. 2013, 51, 320-323.

82. Spinosa, M.R.; Wallet, F.; Courcol, R.J.; Oggioni, M.R. The trouble in tracing opportunistic pathogens: Cholangitis due to Bacillus in a French hospital caused by a strain related to an Italian probiotic? Microb. Ecol. Health Dis. 2000, 12, 99-101.

83. Behnsen, J.; Deriu, E.; Sassone-Corsi, M.; Raffatellu, M. Probiotics: Properties, examples, and specific applications. Cold Spring Harb. Perspect. Med. 2013, 3, doi:10.1101/cshperspect.a010074.

84. Xia, P.; Zhu, J.; Zhu, G. Escherichia coli Nissle 1917 as safe vehicles for intestinal immune targeted therapy-A review. Acta Microbiol. Sin. 2013, 53, 538-544.

85. Savard, P.; Lamarche, B.; Paradis, M.E.; Thiboutot, H.; Laurin, E.; Roy, D. Impact of Bifidobacterium animalis subsp. lactis BB-12 and, Lactobacillus acidophilus LA-5-containing yoghurt, on fecal bacterial counts of healthy adults. Int. J. Food Microbiol. 2011, 149, 50-57.

86. Gueimonde, M.; Salminen, S. Microbiota of the Intestine: Probiotics. Encyclopedia of Human Nutrition, 3rd ed.; Elsevier: Amsterdam, The Netherlands, 2013; pp. 175-181.

87. Goldenberg, J.Z.; Ma, S.S.; Saxton, J.D.; Martzen, M.R.; Vandvik, P.O.; Thorlund, K.; Guyatt, G.H.; Johnston, B.C. Probiotics for the prevention of Clostridium difficile-associated diarrhea in adults and children. Cochrane Database Syst Rev. 2013, 5, doi:10.1002/14651858.CD006095.pub3.

88. Guthmann, F.; Kluthe, C.; Buhrer, C. Probiotics for prevention of necrotising enterocolitis: An updated metaanalysis. Klin. Padiatr. 2010, 222, 284-290.

89. Bernardo, W.M.; Aires, F.T.; Carneiro, R.M.; Sá, F.P.; Rullo, V.E.; Burns, D.A. Effectiveness of probiotics in the prophylaxis of necrotizing enterocolitis in preterm neonates: A systematic review and meta-analysis. J. Pediatr (Rio. J.) 2013, 89, 18-24.

90. AlFaleh, K.; Anabrees, J. Efficacy and safety of probiotics in preterm infants. J. Neonatal. Perinat. Med. 2013, 6, 1-9.

91. Wong, J.M.; de Souza, R.; Kendall, C.W.; Emam, A.; Jenkins, D.J. Colonic health: Fermentation and short chain fatty acids. J. Clin. Gastroent. 2006, 40, 235-243.

92. Wilhelm, S.M.; Johnson, J.L.; Kale-Pradhan, P.B. Treating bugs with bugs: The role of probiotics as adjunctive therapy for Helicobacter pylori. Ann Pharmacother. 2011, 45, 960-966.

93. Hemsworth, J.C.; Hekmat, S.; Reid, G. Micronutrient supplemented probiotic yogurt for HIV-infected adults taking HAART in London, Canada. Gut Microbes. 2012, 3, 414-419.

94. Enos, M.K.; Burton, J.P.; Dols, J.; Buhulata, S.; Changalucha, J.; Reid, G. Probiotics and nutrients for the first 1000 days of life in the developing world. Benef Microbes. 2013, 4, 3-16. 
95. Serban, D.E. Gastrointestinal cancers: Influence of gut microbiota, probiotics and prebiotics. Cancer Lett. 2013, 345, 258-270.

96. Orlando, A.; Russo, F. Intestinal microbiota, probiotics and human gastrointestinal cancers. J. Gastrointest. Cancer. 2013, 44, 121-131.

97. Kmonickova, E.; Kverka, M.; Tlaskalová-Hogenová, H.; Kostecka, P.; Zidek, Z. Stimulation of nitric oxide, cytokine and prostaglandin production by low-molecular weight fractions of probiotic Lactobacillus casei lysate. Neuro Endocrinol Lett. 2012, 33, 166-172.

98. Boyle, R.J.; Bath-Hextall, F.J.; Leonardi-Bee, J.; Murell, D.F.; Tang, M.L. Probiotics for the treatment of eczema: A systematic review. Clin. Exp. Alergy. 2009, 39, 1117-1127.

99. Azad, M.B.; Coneys, J.G.; Kozyrskyj, A.L.; Field, C.J.; Ramsey, C.D.; Becker, A.B.; Friesen, C.; Abou-Setta, A.M.; Zarychanski, R. Probiotic supplementation during pregnancy or infancy for the prevention of asthma and wheeze: Systematic review and meta-analysis. BMJ 2013, 347, doi: 10.1136/bmj.f6471.

100. Elazab, N.; Mendy, A.; Gasana, J.; Vieira, E.R.; Quizon, A.; Forno, E. Probiotic administration in early life, atopy, and asthma: A meta-analysis of clinical trials. Pediatrics 2013, 132, e666-e676.

101. Pedroso, A.A.; Hurley-Bacon, A.L.; Zedek, A.S.; Kwan, T.W.; Jordan, A.P.; Avellaneda, G.; Hofacre, C.L.; Oakley, B.B.; Collett, S.R.; Maurer, J.J.; Lee, M.D. Can probiotics improve the environmental microbiome and resistome of commercial poultry production? Int. J. Environ. Res. Public. Health. 2013, 10, 4534-4559.

102. Punaro, G.R.; Maciel, F.R.; Rodrigues, A.M.; Rogero, M.M.; Bogsan, C.S.; Oliveira, M.N.; Ihara, S.S.; Araujo, S.R.; Sanches, T.R.; Andrade, L.C.; et al. Kefir administration reduced progression of renal injury in STZ-diabetic rats by lowering oxidative stress. Nitric Oxide. 2014, $37,53-60$.

103. Liang, S.; Webb, T.; Li, Z. Probiotic antigens stimulate hepatic natural killer T cells. Immunol. 2014, 141, 203-210.

104. Newaj-Fyzul, A.; Al-Harbi, A.H.; Austin B. Review: Developments in the use of probiotics for disease control in aquaculture. Aquacult. 2013, doi:10.1016/j.aquaculture.2013.08.026.

105. Besselink, M.G.; van Santvoort, H.C.; Buskens, E.; Boermeester, M.A.; van Goor, H.; Timmerman, H.M.; Nieuwenhuijs, V.B.; Bollen, T.L.; van Ramshorst, B.; Witteman, B.J.; et al. Probiotic prophylaxis in predicted severe acute pancreatitis: a randomised, double-blind, placebo-controlled trial. Lancet 2008, 371, 651-659.

106. Hooijmans, C.R.; de Vries, R.B.; Rovers, M.M.; Gooszen, H.G.; Ritskes-Hoitinga, M. The effects of probiotic supplementation on experimental acute pancreatitis: A systematic review and meta-analysis. PLoS One 2012, 7, doi:10.1371/journal.pone.0048811.

107. McClave, S.A.; Heyland, D.K.; Wischmeyer, P.E. Comment on: Probiotic prophylaxis in predicted severe acute pancreatitis: A randomized, double-blind, placebo-controlled trial. J. Parenter Enteral Nutr. 2009, 33, 444-446.

108. Foolad, N.; Armstrong, A.W. Prebiotics and probiotics: The prevention and reduction in severity of atopic dermatitis in children. Benef. Microbes. 2014, doi:10.3920/BM2013.0034.

109. Licciardi, P.V.; Ismail, I.H.; Balloch, A.; Mui, M.; Hoe, E.; Lamb, K.; Tang, M.L. Maternal supplementation with LGG reduces vaccine-specific immune responses in infants at high-risk of developing allergic disease. Front. Immunol. 2013, 4, doi:10.3389/fimmu.2013.00381. 
110. Wickens, K.; Stanley, T.V.; Mitchell, E.A.; Barthow, C.; Fitzharris, P.; Purdie, G.; Siebers, R.; Black, P.N.; Crane, J. Early supplementation with Lactobacillus rhamnosus HN001 reduces eczema prevalence to 6 years: Does it also reduce atopic sensitization? Clin. Exp. Allergy. 2013, 43, 1048-1057.

111. Panwar, H.; Calderwood, D.; Grant, I.R.; Grover, S.; Green, B.D. Lactobacillus strains isolated from infant faeces possess potent inhibitory activity against intestinal alpha- and beta-glucosidases suggesting anti-diabetic potential. Eur. J. Nutr. 2014, doi: 10.1007/s00394-013-0649-9.

112. Jakaitis, B.M.; Denning, P.W. Commensal and probiotic bacteria may prevent NEC by maturing intestinal host defenses. Pathophysiology 2014, 21, 47-54.

113. Homayouni, A.; Bastani, P.; Ziyadi, S.; Mohammad-Alizadeh-Charandabi, S.; Ghalibaf, M.; Mortazavian, A.M.; Mehrabany, E.V. Effects of probiotics on the recurrence of bacterial vaginosis: A review. J. Low Genit. Tract. Dis. 2014, 18, 79-86.

114. Sanchez, M.; Darimont, C.; Drapeau, V.; Emady-Azar, S.; Lepage, M.; Rezzonico, E.; Ngom-Bru, C.; Berger, B.; Philippe, L.; Ammon-Zuffrey, C.; et al. Effect of Lactobacillus rhamnosus CGMCC1.3724 supplementation on weight loss and maintenance in obese men and women. Br. J. Nutr. 2013, 111, 1507-1519.

115. Ciccarelli, S.; Stolfi, I.; Caramia, G. Management strategies in the treatment of neonatal and pediatric gastroenteritis. Infect. Drug Resist. 2013, 6, 133-161.

116. Luoto, R.; Ruuskanen, O.; Waris, M.; Kalliomäki, M.; Salminen, S.; Isolauri, E. Prebiotic and probiotic supplementation prevents rhinovirus infections in preterm infants: A randomized, placebo-controlled trial. J. Allergy Clin. Immunol. 2013, 133, 405-413.

117. Ammoscato, F.; Scirocco, A.; Altomare, A.; Matarrese, P.; Petitta, C.; Ascione, B.; Caronna, R.; Guarino, M.; Marignani, M.; Cicala, M.; et al. Lactobacillus rhamnosus protects human colonic muscle from pathogen lipopolysaccharide-induced damage. Neurogastroenterol. Motil. 2013, doi:10.1111/nmo.12232.

118. Phavichitr, N.; Puwdee, P.; Tantibhaedhyangkul, R. Cost-benefit analysis of the probiotic treatment of children hospitalized for acute diarrhea in Bangkok, Thailand. Southeast Asian J. Trop. Med. Public Health 2013, 44, 1065-1071.

119. Cortés-Zavaleta, O.; López-Malo, A.; Hernández-Mendoza, A.; García, H.S. Antifungal activity of Lactobacilli and its relationship with 3-phenyllactic acid production. Int. J. Food. Microbiol. 2014, 173, 30-35.

120. Mohseni, M.J.; Aryan, Z.; Emamzadeh-Fard, S.; Paydary, K.; Mofid, V.; Joudaki, H.; Kajbafzadeh, A.M. Combination of probiotics and antibiotics in the prevention of recurrent urinary tract infection in children. Iran. J. Pediatr. 2013, 23, 430-438.

121. Ortiz, L.; Ruiz, F.; Pascual, L.; Barberis, L. Effect of two probiotic strains of Lactobacillus on in vitro adherence of Listeria monocytogenes, Streptococcus agalactiae, and Staphylococcus aureus to vaginal epithelial cells. Curr. Microbiol. 2014, doi:10.1007/s00284-014-0524-9.

122. Wu, Z.J.; DU, X.; Zheng, J. Role of Lactobacillus in the prevention of Clostridium difficile-associated diarrhea: A meta-analysis of randomized controlled trials. Chin. Med. J. (Engl.) 2013, 126, 4154-4161. 
123. Kovachev, S.; Dobrevski-Vacheva, R. [Effect of Lactobacillus casei var. rhamnosus (Gynophilus) in restoring the vaginal flora by female patients with bacterial vaginosis-Randomized, open clinical trial]. Akush. Ginekol. (Sofiia) 2013, 52 (Suppl. 1), 48-53.

124. Wright, K.; Wright, H.; Murray, M. Probiotic treatment for the prevention of antibiotic-associated diarrhoea in geriatric patients: A multicentre randomised controlled pilot study. Australas. J. Ageing 2014, doi:10.1111/ajag.12116.

125. Shida, K.; Nomoto, K. Probiotics as efficient immunopotentiators: Translational role in cancer prevention. Indian J. Med. Res. 2013, 138, 808-814.

126. Vaghef-Mehrabany, E.; Alipour, B.; Homayouni-Rad, A.; Sharif, S.K.; Asghari-Jafarabadi, M.; Zavvari, S. Probiotic supplementation improves inflammatory status in patients with rheumatoid arthritis. Nutrition 2013, 30, 430-435.

127. Castillo, N.A.; de Moreno de LeBlanc, A.; Galdeano, C.M.; Perdigón, G. Comparative study of the protective capacity against Salmonella infection between probiotic and nonprobiotic Lactobacilli. J. Appl. Microbiol. 2013, 114, 861-876.

128. Noto Llana, M.; Sarnacki, S.H.; Aya Castañeda Mdel, R.; Bernal, M.I.; Giacomodonato, M.N.; Cerquetti, M.C. Consumption of Lactobacillus casei fermented milk prevents Salmonella reactive arthritis by modulating IL-23/IL-17 expression. PLoS One 2013, 10, doi:10.1371/journal.pone.0082588.

129. Babenko, L.R.; Lazarenko, L.M.; Shynkarenko, L.M.; Mokrozub, V.V.; Pidgorskyi, V.S.; Spivak, M.J. The effect of Lacto- and Bifidobacteria in monoculture on the vaginal microflora in norm and in cases of intravaginal staphylococcosis. Mikrobiol. Z. 2013, 75, 46-55.

130. Qin, Y.; Li, J.; Wang, Q.; Gao, K.; Zhu, B.; Lv, N. [Identification of lactic acid bacteria in commercial yogurt and their antibiotic resistance]. Acta Microbiol. Sin. 2013, 53, 889-897.

131. Moro-García, M.A.; Alonso-Arias, R.; Baltadjieva, M.; Fernández Benítez, C.; Fernández Barrial, M.A.; Díaz Ruisánchez, E.; Alonso Santos, R.; Alvarez Sánchez, M.; Saavedra Miján, J.; López-Larrea, C. Oral supplementation with Lactobacillus delbrueckii subsp. bulgaricus 8481 enhances systemic immunity in elderly subjects. Age (Dordr) 2013, 35, 1311-1326.

132. Abedi, D.; Feizizadeh, S.; Akbari, V.; Jafarian-Dehkordi, A. In vitro anti-bacterial and anti-adherence effects of Lactobacillus delbrueckii subsp bulgaricus on Escherichia coli. Res. Pharm. Sci. 2013, 8, 260-268.

133. Tillisch, K.; Labus, J.; Kilpatrick, L.; Jiang, Z.; Stains, J.; Ebrat, B.; Guyonnet, D.; Legrain-Raspaud, S.; Trotin, B.; Naliboff, B.; Mayer, E.A. Consumption of fermented milk product with probiotic modulates brain activity. Gastroenterology 2013, 144, 1394-1401.

134. Suzuki, S.; Yakabe, T.; Suganuma, H.; Fukao, M.; Saito, T.; Yajima, N. Cell-bound exopolysaccharides of Lactobacillus brevis KB290: protective role and monosaccharide composition. Can. J. Microbiol. 2013, 59, 549-555.

135. Campus, G.; Cocco, F.; Carta, G.; Cagetti, M.G.; Simark-Mattson, C.; Strohmenger, L.; Lingström, P. Effect of a daily dose of Lactobacillus brevis CD2 lozenges in high caries risk schoolchildren. Clin. Oral Investig. 2014, 18, 555-561, 
136. Fujimura, K.E.; Demoor, T.; Rauch, M.; Faruqi, A.A.; Jang, S.; Johnson, C.C.; Boushey, H.A.; Zoratti, E.; Ownby, D.; Lukacs, N.W.; et al. House dust exposure mediates gut microbiome Lactobacillus enrichment and airway immune defense against allergens and virus infection. Proc. Natl. Acad. Sci. USA 2014, 111, 805-810.

137. Hsieh, P.S.; Tsai, Y.C.; Chen, Y.C.; The, S.F.; Ou, C.M.; King, V.A. Eradication of Helicobacter pylori infection by the probiotic strains Lactobacillus johnsonii MH-68 and L. salivarius ssp. salicinius AP-32. Helicobacter 2012, 17, 466-477.

138. Zhang, Y.C.; Zhang, L.W.; Ma, W.; Yi, H.X.; Yang, X.; Du, M.; Shan, Y.J.; Han, X.; Zhang, L.L. Screening of probiotic Lactobacilli for inhibition of Shigella sonnei and the macromolecules involved in inhibition. Anaerobe 2012, 18, 498-503.

139. Lue, K.H.; Sun, H.L.; Lu, K.H.; Ku, M.S.; Sheu, J.N.; Chan, C.H.; Wang, Y.H. A trial of adding Lactobacillus johnsonii EM1 to levocetirizine for treatment of perennial allergic rhinitis in children aged 7-12 years. Int. J. Pediatr. Otorhinolaryngol. 2012, 76, 994-1001.

140. Ortiz-Lucas, M.; Tobías, A.; Saz, P.; Sebastián, J.J. Effect of probiotic species on irritable bowel syndrome symptoms: A bring up to date meta-analysis. Rev. Esp. Enferm. Dig. 2013, 105, 19-36.

141. Chen, P.W.; Jheng, T.T.; Shyu, C.L.; Mao, F.C. Synergistic antibacterial efficacies of the combination of bovine lactoferrin or its hydrolysate with probiotic secretion in curbing the growth of meticillin-resistant Staphylococcus aureus. J. Med. Microbiol. 2013, 62, 1845-1851.

142. Tomaro-Duchesneau, C.; Saha, S.; Malhotra, M.; Jones, M.L.; Labbé, A.; Rodes, L.; Kahouli, I.; Prakash, S. Effect of orally administered L. fermentum NCIMB 5221 on markers of metabolic syndrome: An in vivo analysis using ZDF rats. Appl. Microbiol. Biotechnol. 2014, 98, 115-126.

143. Szajewska, H.; Urbańska, M.; Chmielewska, A.; Weizman, Z.; Shamir, R. Meta-analysis: Lactobacillus reuteri strain DSM 17938 (and the original strain ATCC 55730) for treating acute gastroenteritis in children. Benef. Microbes. 2014, doi:10.3920/BM2013.0056.

144. Anabrees, J.; Indrio, F.; Paes, B.; AlFaleh, K. Probiotics for infantile colic: A systematic review. BMC Pediatr. 2013, 13, 186, doi:10.1186/1471-2431-13-186.

145. Indrio, F.; Di Mauro, A.; Riezzo, G.; Civardi, E.; Intini, C.; Corvaglia, L.; Ballardini, E.; Bisceglia, M.; Cinquetti, M.; Brazzoduro, E.; et al. Prophylactic use of a probiotic in the prevention of colic, regurgitation, and functional constipation: A randomized clinical trial. JAMA Pediatr. 2014, 168, 228-233.

146. Oncel, M.Y.; Sari, F.N.; Arayici, S.; Guzoglu, N.; Erdeve, O.; Uras, N.; Oguz, S.S.; Dilmen, U. Lactobacillus reuteri for the prevention of necrotising enterocolitis in very low birthweight infants: A randomised controlled trial. Arch. Dis. Child. Fetal Neonatal. Ed. 2013, 99, F110-F115.

147. Jacobs, S.E.; Tobin, J.M.; Opie, G.F.; Donath, S.; Tabrizi, S.N.; Pirotta, M.; Morley, C.J.; Garland, S.M; ProPrems Study Group. Probiotic effects on late-onset sepsis in very preterm infants: A randomized controlled trial. Pediatrics. 2013, 132, 1055-1062.

148. Li, D.; Rosito, G.; Slagle, T. Probiotics for the prevention of necrotizing enterocolitis in neonates: An 8-year retrospective cohort study. J. Clin. Pharm. Ther. 2013, 38, 445-449.

149. Janvier, A.; Malo, J.; Barrington, K.J. Cohort study of probiotics in a North American neonatal intensive care unit. J. Pediatr. 2014, doi:10.1016/j.jpeds.2013.11.025. 
150. Pinto, G.S.; Cenci, M.S.; Azevedo, M.S.; Epifanio, M.; Jones, M.H. Effect of yogurt Containing Bifidobacterium animalis subsp. lactis DN-173010 probiotic on dental plaque and saliva in orthodontic patients. Caries Res. 2014, 48, 63-68.

151. Bordoni, A.; Amaretti, A.; Leonardi, A.; Boschetti, E.; Danesi, F.; Matteuzzi, D.; Roncaglia, L.; Raimondi, S.; Rossi, M. Cholesterol-lowering probiotics: In vitro selection and in vivo testing of bifidobacteria. Appl. Microbiol. Biotechnol. 2013, 9, 8273-8281.

152. West, N.P.; Horn, P.L.; Pyne, D.B.; Gebski, V.J.; Lahtinen, S.J.; Fricker, P.A.; Cripps, A.W. Probiotic supplementation for respiratory and gastrointestinal illness symptoms in healthy physically active individuals. Clin. Nutr. 2013, doi:10.1016/j.clnu.2013.10.002.

153. Yu, H.; Liu, L.; Chang, Z.; Wang, S.; Wen, B.; Yin, P.; Liu, D.; Chen, B.; Zhang, J. Genome sequence of the bacterium Bifidobacterium longum strain CMCC P0001, a probiotic strain used for treating gastrointestinal disease. Genome Announc. 2013, doi:10.1128/genomeA.00716-13.

154. Schwarzer, M.; Srutkova, D.; Schabussova, I.; Hudcovic, T.; Akgün, J.; Wiedermann, U.; Kozakova, H. Neonatal colonization of germ-free mice with Bifidobacterium longum prevents allergic sensitization to major birch pollen allergen Bet $\mathrm{v}$ 1. Vaccine 2013, 31, 5405-5412.

155. Lee, J.S.; Chung, M.J.; Seo, J.G. In vitro evaluation of antimicrobial activity of lactic acid bacteria against Clostridium difficile. Toxicol. Res. 2013, 29, 99-106.

156. Fernandez, B.; Hammami, R.; Savard, P.; Jean, J.; Fliss, I. Pediococcus acidilactici UL5 and Lactococcus lactis ATCC 11454 are able to survive and express their bacteriocin genes under simulated gastrointestinal conditions. J. Appl. Microbiol. 2013, doi: 10.1111/jam.12391.

157. Raz, I.; Gollop, N.; Polak-Charcon, S.; Schwartz, B. Isolation and characterisation of new putative probiotic bacteria from human colonic flora. Br. J. Nutr. 2007, 97, 725-734.

158. Mehta, R.; Arya, R.; Goyal, K.; Singh, M.; Sharma, A.K. Bio-preservative and therapeutic potential of pediocin: Recent trends and future perspectives. Recent Pat. Biotechnol. 2013, 7 , 172-178.

159. Kaur, B.; Garg, N.; Sachdev, A.; Kumar, B. Effect of the oral intake of probiotic Pediococcus acidilactici BA28 on Helicobacter pylori causing peptic ulcer in C57BL/6 mice models. Appl. Biochem. Biotechnol. 2014, 172, 973-983.

160. Benmechernene, Z.; Chentouf, H.F.; Yahia, B.; Fatima, G.; Quintela-Baluja, M.; Calo-Mata, P.; Barros-Velázquez, J. Technological aptitude and applications of Leuconostoc mesenteroides bioactive strains isolated from algerian raw camel milk. Biomed. Res. Int. 2013, 2013, doi:10.1155/2013/418132.

161. Ratna Sudha, M.; Yelikar, K.A.; Deshpande, S. Clinical study of Bacillus coagulans unique IS-2 (ATCC PTA-11748) in the treatment of patients with bacterial vaginosis. Indian J. Microbiol. 2012, 52, 396-399.

162. Benson, K.F.; Redman, K.A.; Carter, S.G.; Keller, D.; Farmer, S.; Endres, J.R.; Jensen, G.S. Probiotic metabolites from Bacillus coagulans GanedenBC30 ${ }^{\mathrm{TM}}$ support maturation of antigen-presenting cells in vitro. World J. Gastroenterol. 2012, 18, 1875-1883.

163. Jindal, G.; Pandey, R.K.; Agarwal, J.; Singh, M. A comparative evaluation of probiotics on salivary mutans Streptococci counts in Indian children. Eur. Arch. Paediatr. Dent. 2011, 12, 211-215. 
164. Clark, L.C.; Hodgkin, J. Commensals, probiotics and pathogens in the Caenorhabditis elegans model. Cell Microbiol. 2014, 16, 27-38.

165. Bereswill, S.; Fischer, A.; Dunay, I.R.; Kühl, A.A.; Göbel, U.B.; Liesenfeld, O.; Heimesaat, M.M. Pro-inflammatory potential of Escherichia coli strains K12 and Nissle 1917 in a murine model of acute ileitis. Eur. J. Microbiol. Immunol. (Bp.) 2013, 3, 126-134.

166. Stein, E.; Inic-Kanada, A.; Belij, S.; Montanaro, J.; Bintner, N.; Schlacher, S.; Mayr, U.B.; Lubitz, W.; Stojanovic, M.; Najdenski, H.; et al. In vitro and in vivo uptake study of Escherichia coli Nissle 1917 bacterial ghosts: Cell-based delivery system to target ocular surface diseases. Invest. Ophthalmol. Vis. Sci. 2013, 54, 6326-6333.

167. Deriu, E.; Liu, J.Z.; Pezeshki, M.; Edwards, R.A.; Ochoa, R.J.; Contreras, H.; Libby, S.J.; Fang, F.C.; Raffatellu, M. Probiotic bacteria reduce Salmonella typhimurium intestinal colonization by competing for iron. Cell Host Microbe. 2013, 14, $26-37$.

168. Blaser, M.J.; Falkow, S. What are the consequences of the disappearing human microbiota? Nat. Rev. Microbiol. 2009, 12, 887-894.

169. Gelberg, H.B. Comparative anatomy, physiology, and mechanisms of disease production of the esophagus, stomach, and small intestine. Toxicol. Pathol. 2014, 42, 54-66.

170. Pamer, E.G. Fecal microbiota transplantation: Effectiveness, complexities, and lingering concerns. Mucosal Immunol. 2014, doi:10.1038/mi.2013.117.

171. Blaser M. Antibiotic overuse: Stop the killing of beneficial bacteria. Nature 2011, 476, 393-394.

172. Caselli, M.; Cassol, F.; Calò, G.; Holton, J.; Zuliani, G.; Gasbarrini, A. Actual concept of "probiotics": Is it more functional to science or business? World J. Gastroenterol. 2013, 19, 1527-1540.

173. Grover, S.; Rashmi, H.M.; Srivastava, A.K.; Batish, V.K. Probiotics for human health-New innovations and emerging trends. Gut. Pathog. 2012, 4, doi:10.1186/1757-4749-4-15.

174. Boyle, R.J.; Robins-Browne, R.M.; Tang, M.L. Probiotic use in clinical practice: What are the risks? Am. J. Clin. Nutr. 2006, 83, 1256-1264.

175. Snydman, D.R. The safety of probiotics. Clin. Infect. Dis. 2008, 46, S104-S111.

(C) 2014 by the authors; licensee MDPI, Basel, Switzerland. This article is an open access article distributed under the terms and conditions of the Creative Commons Attribution license (http://creativecommons.org/licenses/by/3.0/). 